\title{
doi:10.1016/S0016-7037(03)00214-X
}

\section{Association of uranyl with the cell wall of Pseudomonas fluorescens inhibits metabolism}

\author{
Rizlan Bencheikh-Latmani* and James O. Leckie \\ Department of Civil and Environmental Engineering, Stanford University, Stanford, CA 94305
}

(Received September 10, 2002; accepted in revised form March 4, 2003)

\begin{abstract}
Citric acid is found along with uranyl in the subsurface of former nuclear facilities because of its use as a decontamination agent in the nuclear industry. Citrate's metal chelating properties affect the mobility of uranyl in the subsurface and consequently, citrate biodegradation may significantly impact uranyl fate and transport. Under the non-growth conditions considered, low (micromolar) uranyl concentrations inhibit the biodegradation of citrate by Pseudomonas fluorescens, a common subsurface denitrifying bacterium. Additionally, uranyl is found readily associated with the cell envelope of $P$. fluorescens. The observed inhibition appears to be linked to the binding of uranyl to the cell surface and is reversible by desorbing cell-bound uranyl. This study establishes a link between uranyl association with the cell surface and the observed inhibitory effect of uranyl on cell metabolism. Copyright (C) 2003 Elsevier Ltd
\end{abstract}

\section{INTRODUCTION}

Uranium is a contaminant of concern in the subsurface environment of a majority of former nuclear fuel and weapons manufacturing facilities of the Department of Energy (DOE) (Riley et al., 1992). In the 1950s and 1960s, wastes containing a mixture of radionuclides and chelators such as citric acid, oxalic acid, ethylenediaminetetraacetic acid (EDTA) or nitrilotriacetic acid (NTA) were disposed of in shallow trenches (Department of Energy, 1997, 1998; Hartman et al., 2000). In several cases, the radionuclides have reached the water table and are threatening water supply wells or surface waters. The chelators are not contaminants in their own right (with the notable exception of NTA) but are important because they have the potential to significantly alter uranyl mobility in the subsurface.

Specifically, citric acid is known to affect uranyl adsorption to mineral surfaces. Citrate has been shown to enhance uranyl adsorption on goethite and to reduce the adsorption of uranyl on kaolinite (Redden et al., 1998). Thus, the mobility of uranyl in the subsurface is crucially linked to the persistence of citric acid and other chelators in the subsurface.

However, citric acid is readily metabolized by a variety of microorganisms, both aerobically and anaerobically (Hugenholtz, 1993; Fuller and Scow, 1997; Coates et al., 1999). An understanding of the propensity of citrate to be biodegraded in the presence of uranyl would be useful in assessing its persistence in uranyl-contaminated environments and thus its role in uranyl fate and transport.

The goal of this study is to investigate the inhibitory effect of uranyl on the biodegradation of citrate by Pseudomonas fluorescens, a common subsurface denitrifier, at environmentally relevant concentrations and under non-growth conditions. The present study differs from others in several ways: (1) The uranyl concentrations used are considerably lower than those in other studies $(<10 \mu \mathrm{mol} / \mathrm{L}$ vs. $>400 \mu \mathrm{mol} / \mathrm{L})$. This is significant because measured uranyl concentrations in contaminated

* Author to whom correspondence should be addressed, at the Scripps Institution of Oceanography, Marine Biology Research Division, 9500 Gilman Drive, La Jolla, CA 92093-0202, USA (rizlan@ucsd.edu). aquifers at circumneutral $\mathrm{pH}$ rarely exceed $30 \mu \mathrm{mol} / \mathrm{L}$ (Department of Energy, 1997). Although DOE sites are heavily contaminated, uranyl sorbs strongly at circumneutral $\mathrm{pHs}$ and the majority of uranyl is associated with the sediments at those pHs. (2) Non-growth conditions were used and are representative of often oligotrophic subsurface environments. Previous studies were conducted under growth conditions in the presence of ample supply of a carbon source. In this study, we examine the metabolism of $P$. fluorescens under non-growth conditions, in the presence of low, environmentally relevant, uranyl and citrate concentrations. (3) Lastly, and most importantly, an additional novelty of this study resides in the fact that it focuses on the relationship between uranyl biosorption and the inhibition of citrate degradation by uranyl and establishes a link between the two.

Several researchers have studied citrate degradation by bacteria in the presence of uranyl but exclusively under growth conditions. Joshi-Tope and Francis (1995) and Francis et al. (1992) showed that, in the presence of equimolar uranyl $(0.52$ $\mathrm{mmol} / \mathrm{L})$, there was no degradation of citrate by $P$. fluorescens. However, in cell-free extract, citrate was fully biodegraded under similar conditions. The authors concluded that the persistence of citrate stemmed from the inability of the cells to transport the uranyl-citrate complex across the cell membrane. Another study by Banaszak et al. (1999) suggests that the uranyl-citrate complex itself is toxic to P. fluorescens. Finally, Huang et al. (1998) show that there is incomplete citrate $(0.55$ $\mathrm{mmol} / \mathrm{L}$ ) degradation by a mixed cell culture in the presence of uranyl $(0.42 \mathrm{mmol} / \mathrm{L})$ at $\mathrm{pH} 6$.

This study shows that uranyl inhibits cell metabolism at low, environmentally relevant concentrations and that the inhibition is associated with the binding of uranyl to the cell envelope. This inhibitory effect is reversible by desorbing cell-bound uranyl.

\section{MATERIALS AND METHODS}

\subsection{Thermodynamic Calculations}

Equilibrium speciation calculations were conducted using the chemical equilibrium program HYDRAQL (Papelis et al., 1988). The thermodynamic data used are shown in Table 1. Briefly, the citrate com- 
Table 1. Thermodynamic constants used in calculation of chemical speciation. The values shown are formation constants adjusted to an ionic strength of 0 .

\begin{tabular}{|c|c|c|}
\hline Species & $\log K$ & Reference \\
\hline 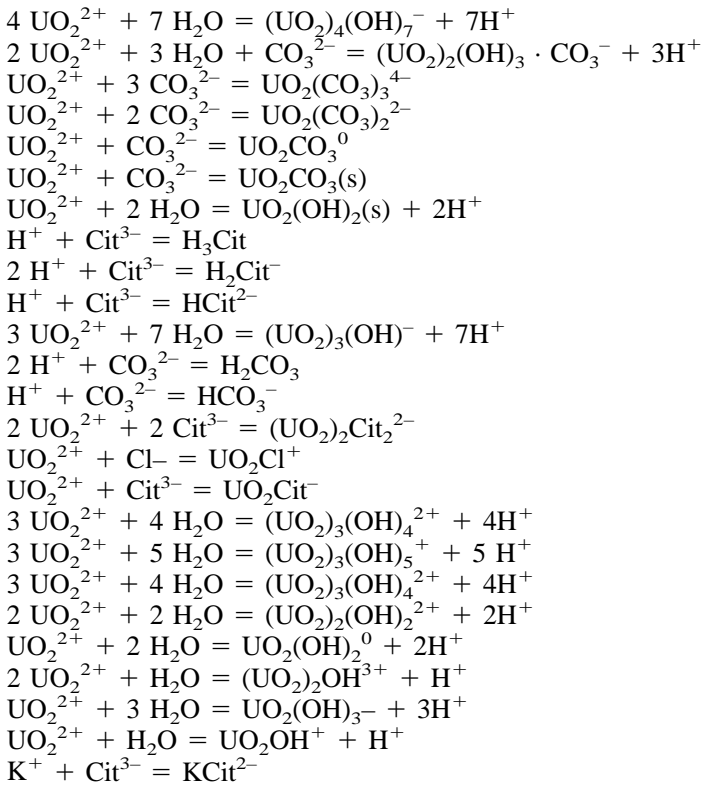 & $\begin{array}{l}-21.9 \\
1.01 \\
21.6 \\
16.94 \\
9.72 \\
14.4 \\
-4.93 \\
14.285 \\
11.157 \\
6.396 \\
-31 \\
16.681 \\
10.329 \\
20.8 \\
0.21 \\
8.00 \\
-33 \\
-15.5 \\
-11.9 \\
-5.62 \\
-12.0 \\
-2.7 \\
-19.2 \\
-5.2 \\
1.22\end{array}$ & $\begin{array}{l}\text { Grenthe et al. (1992) } \\
\text { Grenthe et al. (1992) } \\
\text { Grenthe et al. (1992) } \\
\text { Grenthe et al. (1992) } \\
\text { Grenthe et al. (1992) } \\
\text { Smith et al. (1997) } \\
\text { Grenthe et al. (1992) } \\
\text { Smith et al. (1997) } \\
\text { Smith et al. (1997) } \\
\text { Smith et al. (1997) } \\
\text { Grenthe et al. (1992) } \\
\text { Smith et al. (1997) } \\
\text { Smith et al. (1997) } \\
\text { Smith et al. (1997) } \\
\text { Smith et al. (1997) } \\
\text { Lenhart et al. (2000) } \\
\text { Grenthe et al. (1992) } \\
\text { Grenthe et al. (1992) } \\
\text { Grenthe et al. (1992) } \\
\text { Grenthe et al. (1992) } \\
\text { Langmuir (1997) } \\
\text { Grenthe et al. (1992) } \\
\text { Grenthe et al. (1992) } \\
\text { Grenthe et al. (1992) } \\
\text { Smith et al. (1997) }\end{array}$ \\
\hline
\end{tabular}

plexation data were obtained from Lenhart et al. (2000) and Smith and Martell (1997), the hydrolysis and carbonato complexes data from Grenthe et al. (1992) except for the $\mathrm{UO}_{2}(\mathrm{OH})_{2}{ }^{0}$ complex taken from Langmuir (1997).

\subsection{Cell Growth Conditions}

P. fluorescens is ubiquitous in the subsurface and has been used previously for studies of the biodegradation of metal-citrate complex (Francis et al., 1992; Joshi-Tope and Francis, 1995). P. fluorescens ATCC 55241 biovar II was kindly provided by A. J. Francis (Brookhaven National Laboratory, Upton, NY). Cells of $P$. fluorescens were grown at $25^{\circ} \mathrm{C}$ in a sterile defined mineral salts medium dubbed MM2 and amended with filter-sterilized (Nalgene 0.2- $\mu \mathrm{m}$ PES syringe filter, Nalge Co., Rochester, NY) citric acid (sodium citrate dihydrate, Mallinckrodt, Phillipsburg, NJ) at a final concentration of $1 \mathrm{mmol} / \mathrm{L}$. One liter of MM2 contains $35.8 \mathrm{mg}$ of $\mathrm{NH}_{4} \mathrm{Cl}, 2.75 \mathrm{mg}$ of $\mathrm{CaCl}_{2}$. $2 \mathrm{H}_{2} \mathrm{O}, 6.25 \mathrm{mg}$ of $\mathrm{MgCl}_{2} \cdot 6 \mathrm{H}_{2} \mathrm{O}, 5.5 \mathrm{mg}$ of $\mathrm{KH}_{2} \mathrm{PO}_{4}, 2.585 \mathrm{mg}$ $\mathrm{Fe}\left(\mathrm{SO}_{4}\right)_{2} \mathrm{NH}_{4} \cdot 12 \mathrm{H}_{2} \mathrm{O}, 1.155 \mathrm{mg}$ of $\mathrm{MnSO}_{4} \cdot \mathrm{H}_{2} \mathrm{O}, 0.101 \mathrm{mg}$ of $\mathrm{CuCl}_{2}$ . $2 \mathrm{H}_{2} \mathrm{O}, 0.095 \mathrm{mg}$ of $\mathrm{Na}_{2} \mathrm{MoO}_{4} \cdot 2 \mathrm{H}_{2} \mathrm{O}, 0.165 \mathrm{mg}$ of $\mathrm{ZnSO}_{4} \cdot 7 \mathrm{H}_{2} \mathrm{O}$, $0.151 \mathrm{mg}$ of $\mathrm{CoCl}_{2} \cdot 6 \mathrm{H}_{2} \mathrm{O}, 2.13 \mathrm{~g}$ of MES (2-[N-morpholino]ethanesulfonic acid, Sigma Chemical Co., St. Louis, MO), $7.4 \mathrm{~g}$ of $\mathrm{KCl}$ (Sigma) and was adjusted to $\mathrm{pH} 6.0 \pm 0.1$. After 16 to $18 \mathrm{~h}$ (exponential phase), the cells were harvested by centrifugation at $10,800 \mathrm{~g}$ for $30 \mathrm{~min}$ at $25^{\circ} \mathrm{C}$, washed twice with buffer BS1 and concentrated in BS1 (1 L of cells to $100 \mathrm{~mL})$. BS1 consists of $0.1 \mathrm{~mol} / \mathrm{L} \mathrm{KCl}(7.4 \mathrm{~g} / \mathrm{L})$ and $10^{-2} \mathrm{~mol} / \mathrm{L}$ MES $(2.13 \mathrm{~g} / \mathrm{L})$ at $\mathrm{pH} 6.0 \pm 0.1$. This cell concentrate was used for all experiments.

\subsection{Citrate and Glucose Degradation}

Degradation experiments were conducted in 500-mL polycarbonate (PC) bottles containing $50 \mathrm{~mL}$ of sterile BS1. An adequate volume of filter-sterilized $1 \mathrm{mmol} / \mathrm{L}$ uranyl solution (uranyl nitrate, Johnson Matthey, Ward Hill, MA) and $1 \mathrm{mmol} / \mathrm{L}$ filter-sterilized citrate or 10 $\mathrm{mmol} / \mathrm{L}$ filter-sterilized glucose (D-[+]-glucose anhydrous, Sigma Chemical Co., St. Louis, MO) solution were added to the bottles. In addition, $10 \mu \mathrm{L}(0.1 \mu \mathrm{Ci})$ of filter-sterilized $[1,5]{ }^{14} \mathrm{C}$-citrate (DuPont, DE) or $10 \mu \mathrm{L}(0.1 \mu \mathrm{Ci})$ uniformally labelled ${ }^{14} \mathrm{C}$-glucose (ICN Pharmaceuticals, Irvine, CA) were added to each bottle. Each bottle was prepared in triplicates. The addition of ${ }^{14} \mathrm{C}$ labeled citrate or glucose changes the total concentration by $<1 \%$.

After $30 \mathrm{~min}$, cells were added to each bottle to yield a final $\mathrm{OD}_{600}$ of 0.1 ( $\sim 5 \mathrm{mg}$ protein $/ \mathrm{L}^{-1}$ or $1.4 \times 10^{11}$ cells $\left./ \mathrm{L}^{-1}\right)$. The capped bottles were incubated at $25^{\circ} \mathrm{C}$ on an orbital shaker at $100 \mathrm{rpm}$, in the dark. pH remained within 0.1 unit of $\mathrm{pH} 6.0$ in all cases. During the degradation experiment, samples were collected aseptically from the bottles, filtered through a $0.22-\mu \mathrm{m}$ GVHP filter (Millipore Corporation, Bedford, MA) and the concentration of uranyl and citrate determined. To quantify uranyl, the filtrate was diluted five-fold with nitric acid (final $\mathrm{HNO}_{3}$ concentration 0.2\%; Optima grade, Fisher Scientific, Pittsburgh, PA) and analyzed on an HP 4500 series Inductively Coupled Plasma-Mass Spectrometer (ICP-MS). To quantify ${ }^{14} \mathrm{C}$-citrate, $1 \mathrm{~mL}$ of the filtrate, 1 $\mathrm{mL}$ of MilliQ water and $20 \mu \mathrm{L}$ of concentrated hydrochloric acid (A.C.S. Plus grade, Fisher Scientific, Fair Lawn, NJ) were mixed in a $20-\mathrm{mL}$ scintillation vial and purged with nitrogen gas for $20 \mathrm{~min}$ to remove $\mathrm{CO}_{2}$. The vial was analyzed on a TriCarb 2500 TR/AB Packard Liquid Scintillation Analyzer with $5 \mathrm{~mL}$ of Ultima Gold XR liquid scintillation solution (Packard, Meriden, CT). Cell lysis was monitored by collecting samples, centrifuging them (at 16,000 $\mathrm{g}$ for $30 \mathrm{~min}$ ) and analyzing the supernatant for protein by the colorimetric Bradford method (Biorad Laboratories, Hercules, CA). There was no interference from citrate or uranyl and the method was sensitive enough to detect cell lysis (as defined by passage through a French Pressure Cell (SLM Aminco) at 1000 psi once). For heat-killed cells, the cell concentrate was subjected to $60^{\circ} \mathrm{C}$ for $1 \mathrm{~h}$ before the addition to each bottle. The heat treatment was sufficient to halt citrate degradation. The integrity of the cells was verified by the protein assay described above.

Control experiments were conducted ([citrate] $=1 \mu \mathrm{mol} / \mathrm{L}$, [uranyl] $=0,3$ or $5 \mu \mathrm{mol} / \mathrm{L}$ ) to verify the complete biodegradation of citrate to $\mathrm{CO}_{2}$. The experiments were identical to the ones described above with the difference that a scintillation vial containing $1 \mathrm{~mL}$ of $1 \mathrm{~N} \mathrm{NaOH}$ was suspended in the headspace of the PC bottle using Teflon tape. As ${ }^{14} \mathrm{C}$-citrate was being metabolized, the ${ }^{14} \mathrm{C}-\mathrm{CO}_{2}$ evolved and was captured in the base trap. The bottles were destructively sampled after $25 \mathrm{~h}$. Measuring ${ }^{14} \mathrm{C}-\mathrm{CO}_{2}$ in the base trap produced identical results to measuring ${ }^{14} \mathrm{C}$ remaining in solution. Thus, it was concluded that citrate was fully biodegraded to $\mathrm{CO}_{2}$ and the latter experimental design was adopted for the remainder of the study. 
Table 2. Calculated speciation of uranyl and citrate in solutions with $1 \mu \mathrm{mol} / \mathrm{L}$ uranyl and $1 \mu \mathrm{mol} / \mathrm{L}$ citrate, $3 \mu \mathrm{mol} / \mathrm{L}$ uranyl and $1 \mu \mathrm{mol} / \mathrm{L}$ citrate or $1 \mu \mathrm{mol} / \mathrm{L}$ uranyl and $10 \mu \mathrm{mol} / \mathrm{L}$ glucose at $\mathrm{pH} 6.0$ and atmospheric $P_{\mathrm{CO} 2}$. Free citrate refers to protonated and deprotonated citrate. $\mathrm{UO}_{2}{ }^{2+}$ refers to uranyl in the free ion form, $\mathrm{UO}_{2}{ }^{2+}$ hydroxides and $\mathrm{UO}_{2}{ }^{2+}$ carbonates refer to the sum of all uranyl hydroxide solution complexes and all solution uranyl carbonate species respectively. Carbonate complexes do not become important until $\mathrm{pH}>6.0$.

$1 \mu \mathrm{mol} / \mathrm{L}$ citrate and $1 \mu \mathrm{mol} / \mathrm{L}$ uranyl

Species

Percent uranyl as

Percent citrate as

$1 \mu \mathrm{mol} / \mathrm{L}$ citrate and $3 \mu \mathrm{mol} / \mathrm{L}$ uranyl

$10 \mu \mathrm{mol}$ glucose and $1 \mu \mathrm{mol}$

uranyl

\begin{tabular}{|c|c|c|c|c|c|}
\hline $\mathrm{UO}_{2} \mathrm{Cit}^{-}$ & 22 & 22 & 12 & 37 & \\
\hline$\left(\mathrm{UO}_{2}\right)_{2}(\mathrm{Cit})_{2}{ }^{2-}$ & 1 & 1 & 1 & 3 & \\
\hline Free citrate & & 63 & & 50 & \\
\hline $\mathrm{KCit}^{2-}$ & & 14 & & 14 & \\
\hline $\mathrm{UO}_{2}^{2+}$ & 11 & & 8 & & 14 \\
\hline $\mathrm{UO}_{2}^{2+}$ hydroxides & 50 & & 59 & & 65 \\
\hline $\mathrm{UO}_{2}^{2+}$ carbonates & 15 & & 19 & & 21 \\
\hline
\end{tabular}

\subsection{Uranyl Association With Cells}

The samples intended for uranium analysis were filtered with GVHP filters selected specifically for their low uranyl binding capacity $(<3 \%$ for $1 \mu \mathrm{mol} / \mathrm{L}$ uranyl at $\mathrm{pH}$ 6.0). To determine the localization of uranyl within the cells, we followed the standard method of cell fractionation. Briefly, cells were lysed using a French Press, the lysate (mixture of lysed and intact cells) centrifuged to remove intact cells and large membrane fragments. The supernatant was then ultracentrifuged to separate the cytoplasmic and membrane fractions. A more detailed protocol follows: Bottles were prepared as described above but without ${ }^{14} \mathrm{C}$-citrate and with $3 \mu \mathrm{mol} / \mathrm{L}$ uranyl, incubated in the dark for 23 to $24 \mathrm{~h}$ and centrifuged for $30 \mathrm{~min}$ at $10,800 \mathrm{~g}$. The supernatant was removed and the pellet resuspended in $3 \mathrm{~mL}$ of fresh sterile BS1. The resulting cell concentrate was lysed by three passages through a French Pressure Cell at 1000 psi. The suspension was analyzed for total protein and total uranyl. The lysate was placed in two Eppendorf microcentrifuge tubes (dubbed A and B) and centrifuged at 10,800 $\mathrm{g}$ for $30 \mathrm{~min}$. The supernatants (containing the intracellular fraction and membrane fractions) were analyzed for protein (A) and uranyl (B) respectively. The pellets (containing unbroken cells and a portion of the membrane fraction), were resuspended in $0.5 \mathrm{~mL}$ of concentrated $\mathrm{HNO}_{3}$ (A used for $\mathrm{U}$ analysis) or in $0.5 \mathrm{~mL}$ of MilliQ water (B used for protein measurement). Analysis of total protein before centrifugation and protein in the supernatant and in the pellet allowed the calculation of the efficiency of cell lysis. The supernatant (combined from A and B) was transferred to a polycarbonate ultracentrifuge tube and centrifuged at $208,000 \mathrm{~g}$ for $2 \mathrm{~h}$ at $4^{\circ} \mathrm{C}$. The supernatant from ultracentrifugation represents the cytoplasmic fraction and was analyzed for uranium. The pellet (membrane fraction) was resuspended in $1 \mathrm{~mL}$ of concentrated $\mathrm{HNO}_{3}$ and measured for $\mathrm{U}$.

\subsection{Viability}

To determine the effect of uranyl on cell viability, bottles were prepared as described above and sampled periodically. The samples were diluted $10^{4}$ - to $10^{5}$-fold with sterile BS1 and $100 \mu \mathrm{L}$ of the dilute solution plated onto tryptone glucose extract agar (Difco Laboratories, Detroit, MI) in triplicates. The plates were incubated at $30^{\circ} \mathrm{C}$ for $24 \mathrm{~h}$ and the colonies counted manually.

\subsection{Reversibility of Inhibition}

Bottles containing sterile BS1 $(50 \mathrm{~mL}), 10 \mu \mathrm{mol} / \mathrm{L}$ citrate (with 10 $\mathrm{nmol} / \mathrm{L}$ of ${ }^{14} \mathrm{C}$ tracer), $20 \mu \mathrm{mol} / \mathrm{L}$ uranyl and cells at a final $\mathrm{OD}_{600}$ of 0.3 were incubated in the dark for $4 \mathrm{~h}$ and centrifuged at $10,800 \mathrm{~g}$ for 30 $\mathrm{min}$. The supernatant was analyzed for $\mathrm{U}$. The cells were resuspended in $50 \mathrm{~mL}$ of $0.1 \mathrm{~mol} / \mathrm{L}$ of $\mathrm{KHCO}_{3}$ and incubated in the dark for $1 \mathrm{~h}$. The bottles were then centrifuged and the supernatant analyzed for uranyl and discarded. It was replaced by $50 \mathrm{~mL}$ of BS1 containing $10 \mu \mathrm{mol} / \mathrm{L}$ of citrate spiked with ${ }^{14} \mathrm{C}$-citrate and citrate degradation was measured over time. At the end of the experiment, the bottles were centrifuged, the pellets dissolved in $1 \mathrm{~mL}$ of concentrated $\mathrm{HNO}_{3}$ and analyzed for uranyl.

\subsection{Electron Microscopy}

Suspensions of freshly grown cells (final $\mathrm{OD}_{600}$ of 0.26 or 0.13 ) containing 10,40 or $100 \mu \mathrm{mol} / \mathrm{L}$ uranyl and $1 \mu \mathrm{mol} / \mathrm{L}$ citrate were incubated in the dark for $24 \mathrm{~h}$. The cells were pelleted (at 10,800 $\mathrm{g}$ for $30 \mathrm{~min}$ ), fixed in $2 \%$ glutaraldehyde (EM grade Polysciences Inc., PA), dehydrated in an ethanol gradient series (70, 80, 90 and 100\% ethanol) and embedded in Spurr low viscosity resin (Polysciences Inc., PA). Subsequently, the polymerized resin was thin-sectioned using a Reichert Ultracut S microtome and imaged with a Philips Transmission Electron Microscope TEM300 (equiped with Gatan, Bioscan CCD camera) at $80 \mathrm{kV}$ using a $20-\mu \mathrm{m}$ aperture. The Energy Dispersive $\mathrm{X}$-ray spectra were collected with an EDAX DX-4.

\subsection{Spectrophotometry}

To determine whether cells outcompete citrate for uranyl in BS1, the absorbance spectrum of the uranyl-citrate complex was monitored before and after the addition of heat-killed cells. The uranyl-citrate complex absorbs at $437 \mathrm{~nm}$ (Dodge and Francis, 1997) and the uranyl cation at $420 \mathrm{~nm}$. Citrate does not absorb in the 400 to $500 \mathrm{~nm}$ range. Uranyl and citrate (each $100 \mu \mathrm{mol} / \mathrm{L}$ ) were placed in BS1 buffer and a spectrum collected in the range 400 to $500 \mathrm{~nm}$ on a Perkin Elmer Lambda Bio spectrometer in a 10-cm path length cell. Heat killed cells $\left(\mathrm{OD}_{600} 0.2\right.$ or 0.5$)$ were added and after a short equilibration ( 2 or 5 min), a sample was filtered and a spectrum collected.

\section{RESULTS}

\subsection{Fate of Uranyl}

Numerous uranyl-citrate complexes have been proposed in the literature: a 1:1 uranyl-citrate complex (Newman et al., 1951; Rajan and Martell, 1965; Markovits et al., 1972; Nunes and Gil, 1987; Lenhart et al., 2000), a 2:1 complex (Nunes and Gil, 1987), a 2:2 complex (Newman et al., 1951; Feldman et al., 1954; Rajan and Martell, 1965; Markovits et al., 1972; Nunes and Gil, 1987; Allen et al., 1996), a 2:3 complex (Dodge and Francis, 1997), a 3:2 complex (Feldman et al., 1954) and a hexameric complex (Rajan and Martell, 1965). In our speciation calculations, we consider only the complexes for which a formation constant exists: the mononuclear (1:1) and binuclear (2:2) complexes. Thermodynamic calculations indicate that at the micromolar concentrations used in our experiments, the mononuclear complex dominates (Table 2). A complete list of 


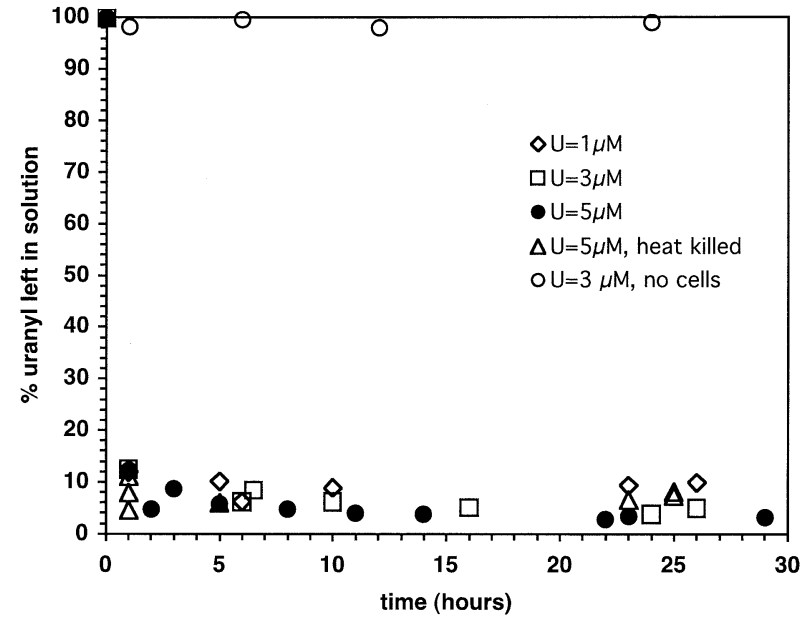

Fig. 1. Percent of initial uranyl remaining in solution after addition of $P$. fluorescens cells (added at $t=0$ and with an $\mathrm{OD}_{600} 0.1$ ) in BS1 and in the presence of $1 \mu \mathrm{mol} / \mathrm{L}$ citrate. Initial uranyl is 1,3 or 5 $\mu \mathrm{mol} / \mathrm{L}$ at $\mathrm{pH}$ 6.0. Controls with heat-killed cells or no cells are shown.

the thermodynamic data used in the speciation calculations is given in Table 1.

The empirical determination of a formation constant for the mononuclear U:cit complex by three independent research groups resulted in three different values: $\log \beta_{1,1}=7.4,6.7$ and 6.3 at $I=0.1$ (respectively Rajan and Martell, 1965; Lenhart et al., 2000; and Markovits et al., 1972). Lenhart et al. (2000) studied the formation of the mononuclear uranyl:citrate complex in $\mathrm{NaClO}_{4}$ at $I=0.1$ at $\mathrm{U}_{\mathrm{T}}=1$ $\mu \mathrm{mol} / \mathrm{L}$ and $[\text { citrate }]_{\mathrm{T}}=20 \mu \mathrm{mol} / \mathrm{L}$ to $0.6 \mathrm{mmol} / \mathrm{L}$ at $\mathrm{pH} 4.0$ and 5.0. The experimental conditions in our study were similar with $\mathrm{U}_{\mathrm{T}}=1$ to $5 \mu \mathrm{mol} / \mathrm{L}$, [citrate $]_{\mathrm{T}}=1 \mu \mathrm{mol} / \mathrm{L}$ and $\mathrm{pH} 6.0$. In contrast, the complexation constants determined by Rajan and Martell (1965) were obtained at considerably higher uranyl and citrate concentrations 0.68 to $17 \mathrm{mmol} / \mathrm{L}$ at the same $I=$ 0.1 Markovits et al. (1972) obtained their constants at $I=1.0$ and $U$ and citrate concentrations $=30 \mu \mathrm{mol} / \mathrm{L}$ to $1.2 \mathrm{mmol} / \mathrm{L}$. Therefore, we used the complexation constant determined under experimental conditions most akin to ours (Lenhart et al., 2000) as is reflected in Table 1.

The thermodynamic calculations predict that $100 \%$ of the uranyl present is in solution (Table 2). This prediction is confirmed by experimental data collected in the absence of cells and showing $\sim 100 \%$ uranyl in solution over the time frame of our experiments (Fig. 1). However, in the presence of cells, $<10 \%$ of uranyl is measured in solution (Fig. 1). These data suggest a strong association of uranyl with cells. The association of uranyl with cells is likely to be due to sorption of uranyl to cells rather than intracellular uptake of uranyl because heat-killed cells scavenge uranyl as effectively as metabolically active cells (Fig. 1).

Thermodynamic calculations predict that $22 \%$ of citrate will be bound in a uranyl-citrate complex (Table 2) for $[\mathrm{U}]=$ [cit $]$ $=1 \mu \mathrm{mol} / \mathrm{L}$. However, due to the uncertainty in the thermodynamic data, it is not possible to state with certainty what fraction of the $\sim 90 \%$ uranyl scavenged by cells (Fig. 1) was initially bound with citrate. Also, the uranyl and citrate concentrations are too low to directly measure the initial presence

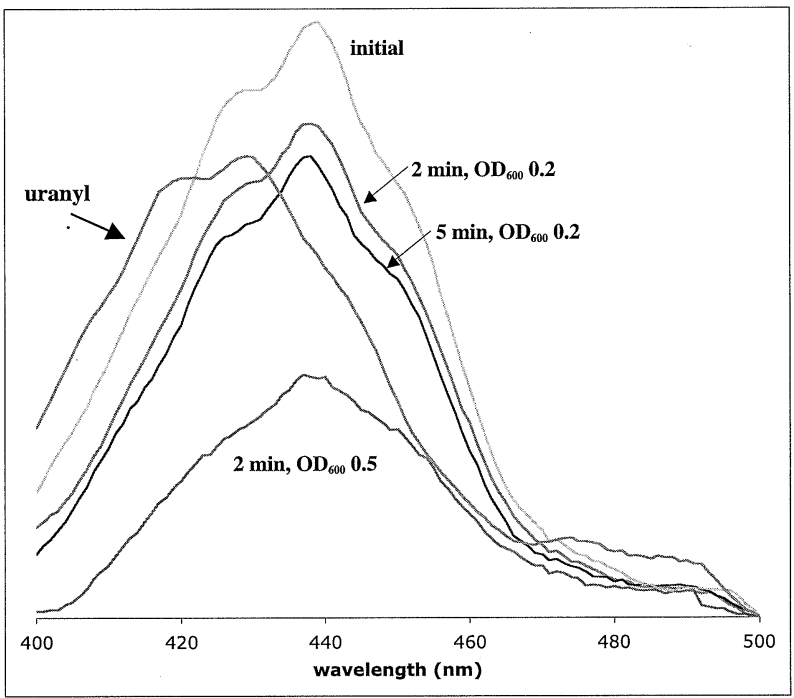

Fig. 2. Absorbance of the uranyl-citrate complex in BS1 before and after addition of $P$. fluorescens cells. The spectra 2 and 5 min after the addition of heat-killed cells $\left(\mathrm{OD}_{600} 0.2\right)$ are shown. Also, the spectrum 2 min after addition of cells $\left(\mathrm{OD}_{600} 0.5\right)$ and the spectrum with no citrate are shown. [uranyl $]_{\mathrm{T}}=[\text { citrate }]_{\mathrm{T}}=100 \mu \mathrm{mol} / \mathrm{L}, \mathrm{pH} 6.0$.

of the uranyl-citrate complex. At higher uranyl and citrate concentrations, at which it is possible to monitor the uranylcitrate complex(es) by spectrophotometry (Fig. 2), the dissociation of the uranyl-citrate complex in the presence of cells is clearly observed. The uranyl-citrate complex has a characteristic absorption spectrum with a peak at $437 \mathrm{~nm}$ (Dodge and Francis, 1997). The peak appears immediately upon mixing $100 \mu \mathrm{mol} / \mathrm{L}$ uranyl and $100 \mu \mathrm{mol} / \mathrm{L}$ citrate in a $0.1 \mathrm{~mol} / \mathrm{L} \mathrm{KCl}$ solution buffered at pH 6.0 with $10 \mathrm{mmol} / \mathrm{L} \mathrm{MES}$. Addition of heat-killed cells $\left(\mathrm{OD}_{600} 0.2\right)$, equilibration for 2 to $5 \mathrm{~min}$ followed by the removal of cells by filtration show a steady disappearance of the peak. The uranyl-citrate peak decreases by $17 \%$ after 2 min of equilibration with cells and by $22 \%$ after 5 min. Moreover, the addition of a higher cell concentration $\left(\mathrm{OD}_{600} 0.5\right)$ results in a more dramatic disappearance $(59 \%)$ of the uranyl-citrate peak. The characteristic uranyl peak at 420 $\mathrm{nm}$ (Fig. 2) does not appear, suggesting that uranyl is not released into solution. These data show that, under these conditions, the uranyl-citrate complex initially present dissociates in the presence of metabolically inactive cells and that the uranyl released from the complex binds to cells. Thus, under these conditions, cells outcompete citrate for uranyl and strip off uranyl from the preformed uranyl-citrate complex. These results suggest that $P$. fluorescens cells act as a ligand for uranyl and may participate in the speciation of the cation.

We have conducted an empirical study of the kinetics of formation of the uranyl-citrate complexes to confirm their formation within the equilibration time. The results are shown in Figure 3. The spectrum obtained immediately upon mixing of uranyl and citrate is identical to that obtained after 1 week of equilibration under sterile conditions. The kinetics of formation of the complex appear to be extremely rapid and the complex(es) can be assumed to form instantaneously. 


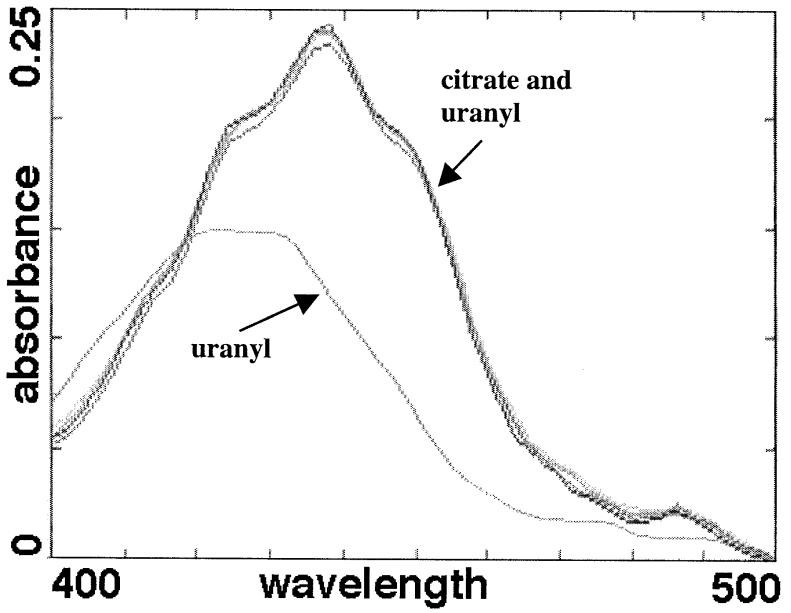

Fig. 3. UV-VIS spectra of uranyl and citrate (5 and $12.5 \mathrm{mmol} / \mathrm{L}$ respectively at $\mathrm{pH}$ 5.2) upon mixing, after $1 \mathrm{~h}, 24 \mathrm{~h}$ and 1 week are identical. The spectrum of $5 \mathrm{mmol} / \mathrm{L}$ uranyl at $\mathrm{pH} 4.16$ is also shown.

\subsection{Inhibitory Effect of Uranyl}

The ability of $P$. fluorescens to degrade citrate under nongrowth conditions and in the presence of low, environmentally relevant, concentrations of uranyl was evaluated. $P$. fluorescens degrades citrate $(1 \mu \mathrm{mol} / \mathrm{L})$ at an initial rate of $0.12 \mu \mathrm{mol} \cdot \mathrm{h}^{-1}$ - $\mathrm{mg}$ protein ${ }^{-1}$ under non-growth conditions (Fig. 4) as indicated by the rapid drop in the solution concentration of ${ }^{14} \mathrm{C}$ citrate. In the presence of equimolar uranyl, the initial rate of citrate degradation is similar at $0.1 \mu \mathrm{mol} \cdot \mathrm{h}^{-1} \cdot \mathrm{mg}$ protein $^{-1}$ (Fig. 4). At increasing uranyl concentrations, citrate degradation is slower (initial degradation rate of 0.035 and $0.025 \mu \mathrm{mol}$ $\cdot \mathrm{h}^{-1} \cdot \mathrm{mg}$ protein ${ }^{-1}$ for 3 and $5 \mu \mathrm{mol} / \mathrm{L}$ uranyl respectively) and ceases at a higher remaining citrate concentration (Fig. 4). In the presence of $3 \mu \mathrm{mol} / \mathrm{L}$ uranyl, $45 \%$ of citrate is degraded after $25 \mathrm{~h}$ whereas only $18 \%$ is consumed in the presence of 5 $\mu \mathrm{mol} / \mathrm{L}$ uranyl in the same time interval (Fig. 4). In the pres-

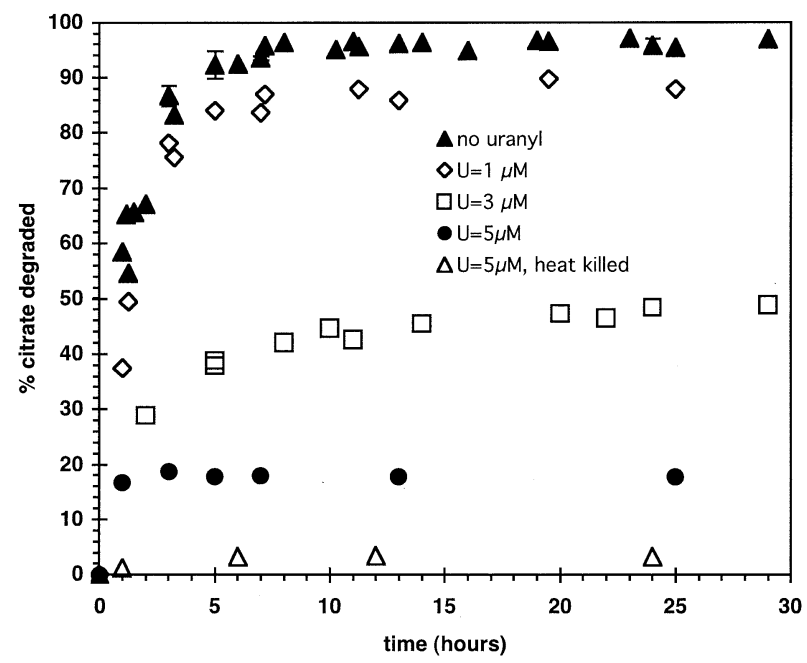

Fig. 4. Citrate $(1 \mu \mathrm{mol} / \mathrm{L})$ degradation in BS1 by $P$. fluorescens $\left(\mathrm{OD}_{600} 0.1\right)$ in the absence of uranyl and in the presence of 1,3 or 5 $\mu \mathrm{mol} / \mathrm{L}$ uranyl at $\mathrm{pH}$ 6.0. The control with heat-killed cells is included.

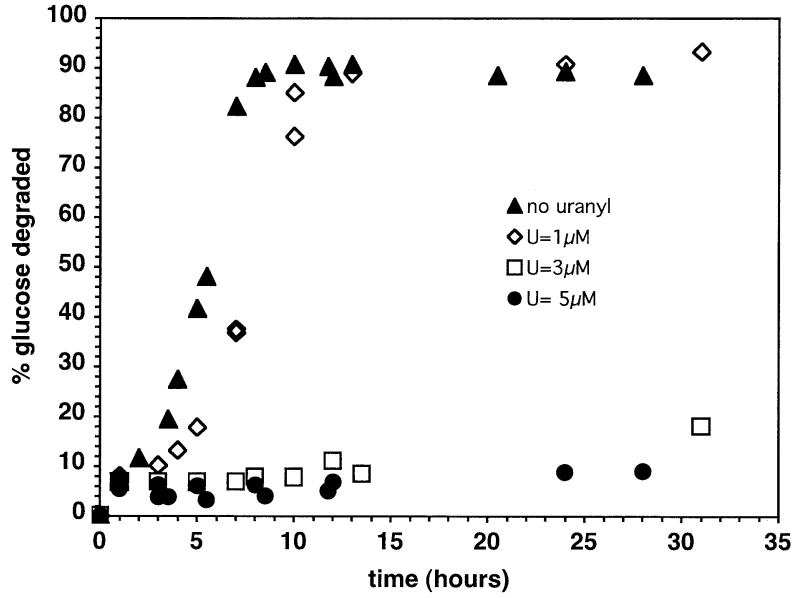

Fig. 5. Degradation of glucose $(10 \mu \mathrm{mol} / \mathrm{L})$ by $P$. fluorescens $\left(\mathrm{OD}_{600}\right.$ $0.1)$ in BS1 in the absence of uranyl, in the presence of $1,35 \mu \mathrm{mol} / \mathrm{L}$ uranyl at $\mathrm{pH}$ 6.0.

ence of heat-killed cells, citrate is not degraded and remains in solution (Fig. 4).

There are two plausible explanations for the observed decrease in the rate of citrate degradation with increasing uranyl concentration: (1) at higher ( 3 or $5 \mu \mathrm{mol} / \mathrm{L}$ ) uranyl concentrations, the concentration of the bioavailable citrate species (assuming that uranyl-citrate complex itself is not bioavailable) is significantly lower than the half-velocity coefficient $\left(K_{m}\right)$ for citrate degradation and thus the degradation rate of citrate is minimal; or (2) uranyl inhibits the metabolism of P. fluorescens and increasing uranyl concentrations shut down citrate metabolism with increasing efficiency. The former (1) is unlikely because there is at least $0.5 \mu \mathrm{mol} / \mathrm{L}$ citrate $(50 \%$ of the total citrate) that is not complexed to uranyl in the presence of 5 $\mu \mathrm{mol} / \mathrm{L}$ uranyl, yet only $18 \%$ is degraded (Fig. 4). At least 0.5 $\mu \mathrm{mol} / \mathrm{L}$ citrate is not complexed to uranyl because, according to Figure 1 , only $0.5 \mu \mathrm{mol} / \mathrm{L}$ uranyl remains in solution in the presence of cells. The maximum concentration of complexed citrate equals the total concentration of uranyl: $0.5 \mu \mathrm{mol} / \mathrm{L}$ citrate.

Glucose was used as a substrate to unambiguously deconvolute a potential inhibitory effect from the effect of a low substrate concentration. Glucose is not known to complex uranyl and therefore uranyl is only present as the free ion, the hydroxy and the carbonato complexes (Table 1) and the amount of bioavailable glucose can be measured directly.

The effect of uranyl on glucose degradation by $P$. fluorescens is similar to that on citrate degradation (Fig. 5). In the presence of $1 \mu \mathrm{mol} / \mathrm{L}$ uranyl, the initial rate of glucose degradation is slightly lower than in the absence of uranyl $(0.16 \mathrm{vs} .0 .11 \mu \mathrm{mol}$ glucose $\cdot \mathrm{h}^{-1} \cdot \mathrm{mg}$ protein $\left.{ }^{-1}\right)$. At higher uranyl concentrations (3 and $5 \mu \mathrm{mol} / \mathrm{L}$ ), glucose degradation does not exceed $15 \%$ after $30 \mathrm{~h}$ (and the initial rate is $0.04 \mu \mathrm{mol}$ glucose $\cdot \mathrm{h}^{-1} \cdot \mathrm{mg}$ protein $^{-1}$ ). We deduce that, under the present conditions, micromolar uranyl has an inhibitory effect on the metabolism of glucose and citrate by $P$. fluorescens. To confirm that deduction, we conducted viability tests for cells exposed to uranyl and citrate or uranyl and glucose.

Figure 6 shows the colony forming units (CFU) counted on 

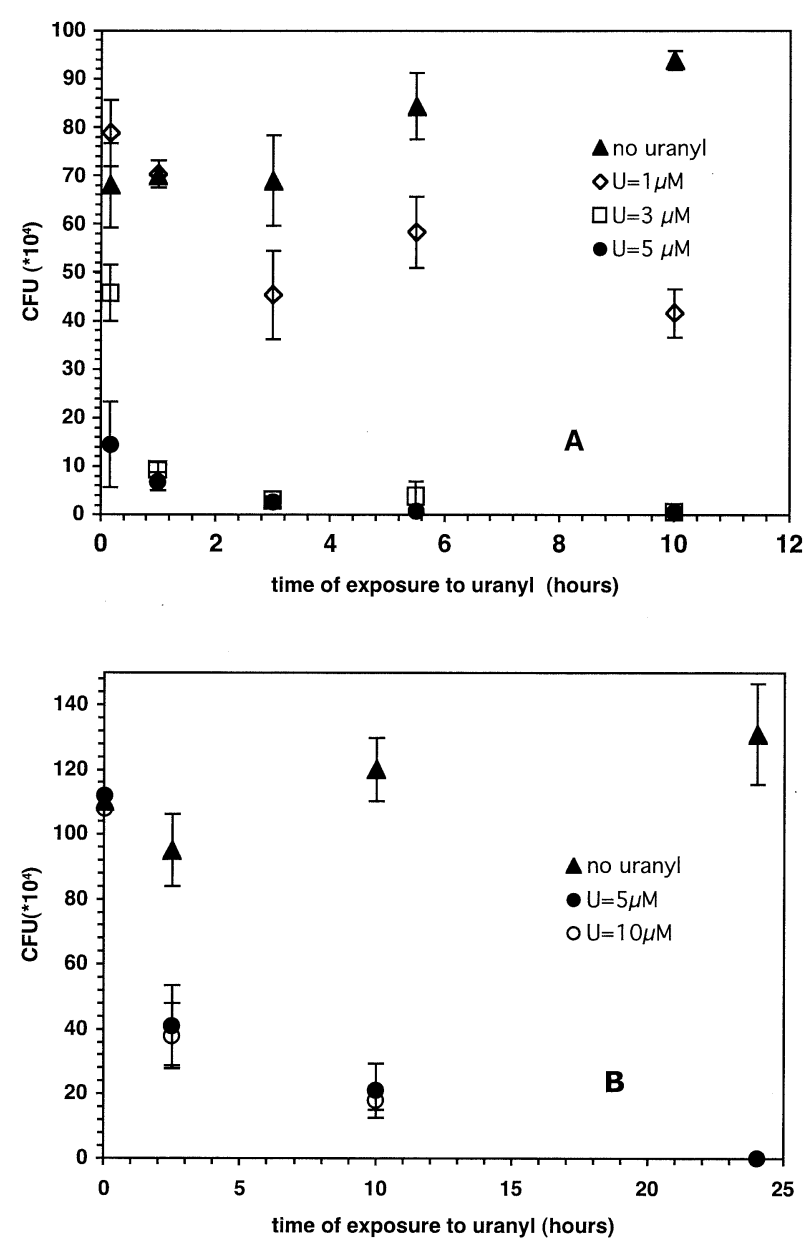

Fig. 6. Colony forming units $(\mathrm{CFU})$ of $P$. fluorescens $\left(1.4 \times 10^{11}\right.$ cells $\cdot \mathrm{L}^{-1}$ ) exposed to $1 \mu \mathrm{mol} / \mathrm{L}$ citrate (panel A) or $10 \mu \mathrm{mol} / \mathrm{L}$ glucose (panel B) and various concentrations of uranyl for the number of hours corresponding to the $\mathrm{x}$-axis and diluted by $10^{4}$ in BS1 before plating on tryptone glucose plates.

agar plates after $P$. fluorescens cells were exposed to uranyl (various concentrations) and $1 \mu \mathrm{mol} / \mathrm{L}$ citrate (panel A) or 10 $\mu \mathrm{mol} / \mathrm{L}$ glucose (panel B) for varying durations. Total cell counts of cells not exposed to uranyl do not change significantly, whereas CFU of cells exposed to uranyl decrease over the duration of exposure. In particular, cells exposed to 3,5 or $10 \mu \mathrm{mol} / \mathrm{L}$ uranyl show a precipitous decrease in CFU. Cells exposed to uranyl and citrate for $3 \mathrm{~h}$ and plated on a solid agar medium devoid of uranyl display a $>70$-fold decrease in viable cell counts (Fig. 6A). A similar behavior is observed for cells exposed to uranyl and glucose (Fig. 6B). These results confirm the above suggestion that uranyl inhibits both citrate and glucose metabolism.

The inhibition of $P$. fluorescens metabolism by uranyl can be reversed by adding a strong U(VI) complexing agent to the solution. Figure 7 shows the degradation of citrate (1) for cells never exposed to uranyl, (2) for cells exposed to uranyl and washed in $0.1 \mathrm{~mol} / \mathrm{L}$ potassium bicarbonate and (3) for cells in the presence of uranyl. After washing the cells with a bicarbonate solution, a significant recovery in activity ensues (Fig. 7). Cells were lost during the wash procedure, thus the ob-

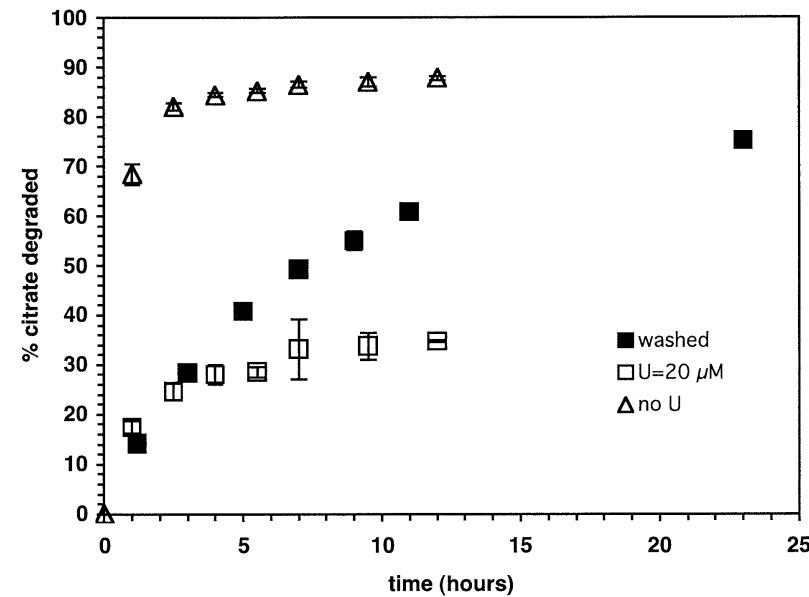

Fig. 7. Citrate $(10 \mu \mathrm{mol} / \mathrm{L})$ degradation in $\mathrm{BS} 1$ by $P$. fluorescens $\left(\mathrm{OD}_{600} 0.3\right)$ cells never exposed to uranyl, in the presence of $20 \mu \mathrm{mol} / \mathrm{L}$ uranyl, exposed to $20 \mu \mathrm{mol} / \mathrm{L}$ uranyl for $4 \mathrm{~h}$ and washed with $0.1 \mathrm{~mol} / \mathrm{L}$ $\mathrm{KHCO}_{3}$.

served rate of citrate degradation after washing (seen on Fig. 7) is an underestimate relative to the rate normalized to cell mass. More accurately, the calculated rate of citrate degradation is $0.04 \mu \mathrm{mol} \cdot \mathrm{h}^{-1} \cdot \mathrm{mg}$ protein $^{-1}$ for unwashed cells as compared to $0.18 \mu \mathrm{mol} \cdot \mathrm{h}^{-1} \cdot \mathrm{mg}$ protein ${ }^{-1}$ for washed cells. The rate of citrate degradation for washed cells remains well below the rate for cells never exposed to uranyl $\sim 0.6 \mu \mathrm{mol} \cdot \mathrm{h}^{-1} \cdot \mathrm{mg}$ protein $^{-1}$.

Cell washing with a bicarbonate solution correlates directly with the recovery of uranyl in solution. Figure 8 shows the amount of uranyl in solution after washing. Approximately $90 \%$ of the uranyl associated with cells is recovered by washing

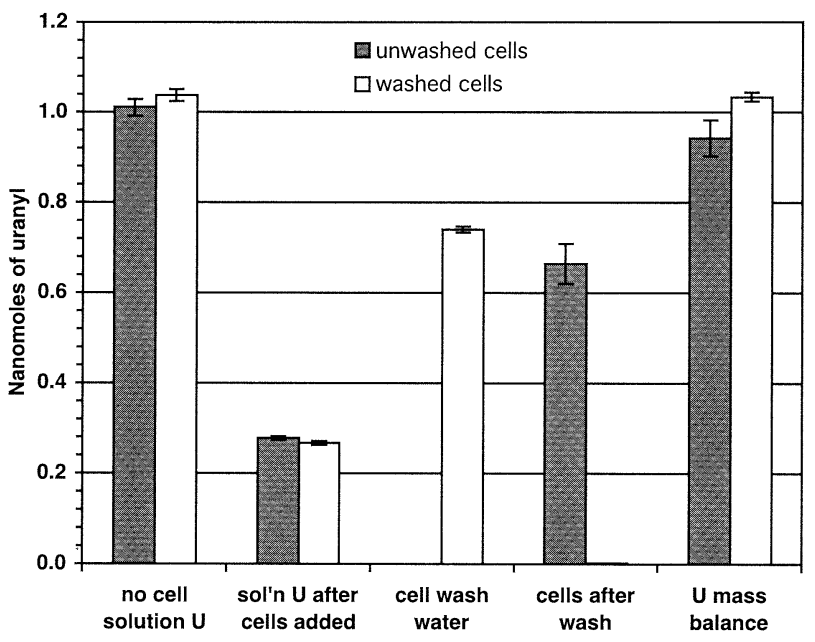

Fig. 8. Distribution of uranyl $(20 \mu \mathrm{mol} / \mathrm{L})$ in BS1 solution containing $10 \mu \mathrm{mol} / \mathrm{L}$ citrate in the presence of unwashed cells (filled) and washed cells (blank). Column 1: initial uranyl concentration in solution before cell addition. Column 2: uranyl concentration in solution after cell addition. Column 3: uranyl in bicarbonate wash solution after the wash. Column 4: uranyl associated with the cells. Column 5: mass balance of uranyl is equal to the sum of uranyl left in solution after cell addition (column 2), uranyl recovered by washing (column 3) and uranyl associated with cells (column 4). 


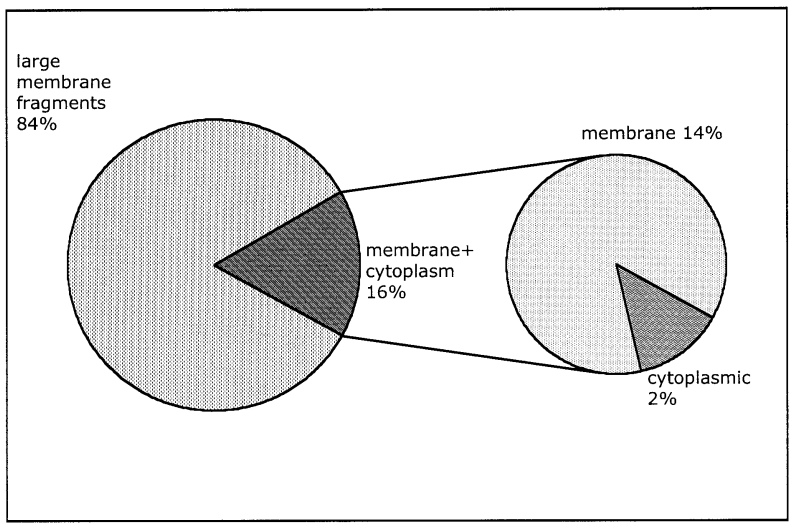

Fig. 9. Distribution of uranyl in cellular fractions after French Pressing and slow centrifugation (large pie) and after ultra-centrifugation of the supernatant from the slow centrifugation (small pie). Unlysed cells in the pellet after slow centrifugation were accounted for and their contribution to the slow centrifugation pellet subtracted.

with $0.1 \mathrm{~mol} / \mathrm{L}$ bicarbonate. Carbonate is a strong complexing agent for uranyl and strips uranyl from the cell surface by forming uranyl-carbonate complexes in solution. The amount of uranyl associated with washed cells is negligible (Fig. 8). The metabolic inhibition of $P$. fluorescens by uranyl appears to be associated with the passive binding of uranyl to cells. The binding is passive (i.e., does not require the use of energy by cells) because heat-killed cells scavenge uranyl as effectively as live cells (Fig. 1).

The recovery of metabolic activity after treatment with bicarbonate is consistent with the results from the viability experiments (Fig. 6). Cells exposed to uranyl $(3,5$ or $10 \mu \mathrm{mol} / \mathrm{L})$ and plated on agar grew poorly (Fig. 6) because the dilution in BS1 buffer $(0.1 \mathrm{~mol} / \mathrm{L} \mathrm{KCl}$ and $10 \mathrm{mmol} / \mathrm{L} \mathrm{MES})$ carried out before plating did not remobilize the uranyl into solution. Uranyl was still associated with cells when they were plated on agar and consequently, the cells were unable to metabolize the tryptone glucose substrate and could not grow.

\subsection{Localization of Uranyl Within Cells}

Treatment with bicarbonate recovers 85 to $95 \%$ of the initial uranyl (Fig. 8). This suggests that (1) most of the uranyl is associated with the outside of the cell and that (2) the uranylcell interaction is a relatively labile "complex." To confirm the former suggestion, we conducted cell fractionation and thinsection TEM (Transmission Electron Microscopy) analyses of cells exposed to uranyl. Cell fractionation demonstrated the presence of uranyl in the membrane fraction (Fig. 9). Approximately $98 \%$ of uranyl was associated with the membrane fraction (Fig. 9).

Thin-section TEM micrographs (Figs. 10 and 11) further confirm the localization of uranyl. Uranyl (the only electrondense atom present in the sample) is clustered in the membrane(s) (Fig. 11). Uranyl is associated with both the outer and the cytoplasmic membranes and also deposits along the periplasm separating the two membranes (Fig. 10). Finally, Energy Dispersive X-ray (EDX) analysis confirms that the deposit is indeed $U$ and shows no significant contribution from potential contaminants such as Fe (Fig. 12).

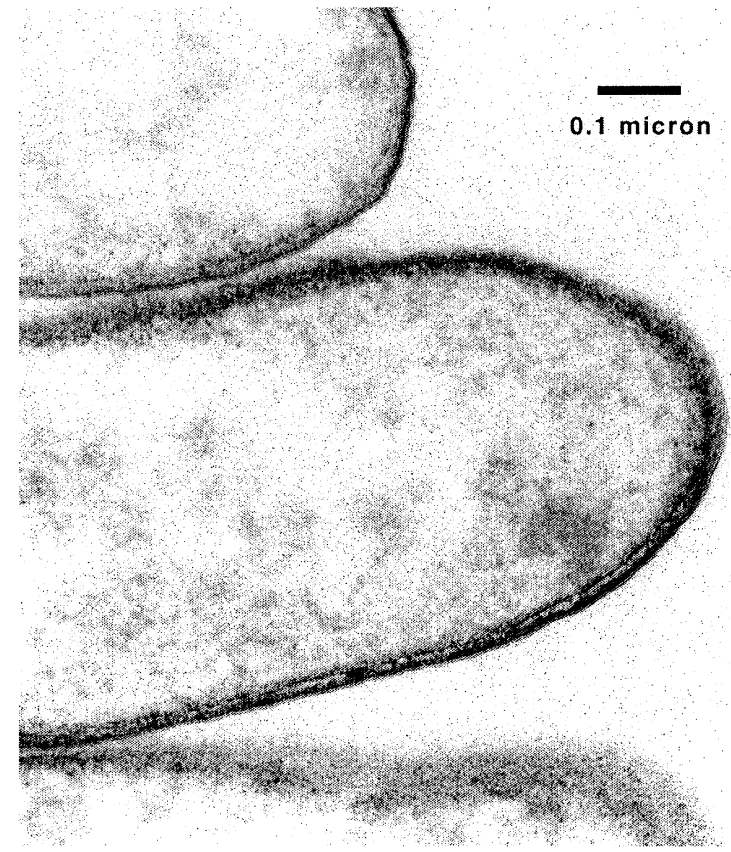

Fig. 10. Transmission electron micrograph of $P$. fluorescens cells exposed to $100 \mu \mathrm{mol} / \mathrm{L}$ uranyl. The samples have not been stained. High electron density corresponds to the presence of uranyl. The membranes (both outer and inner) are significantly darker than the cytoplasm which indicates that uranyl accumulates in the membranes and periplasm.

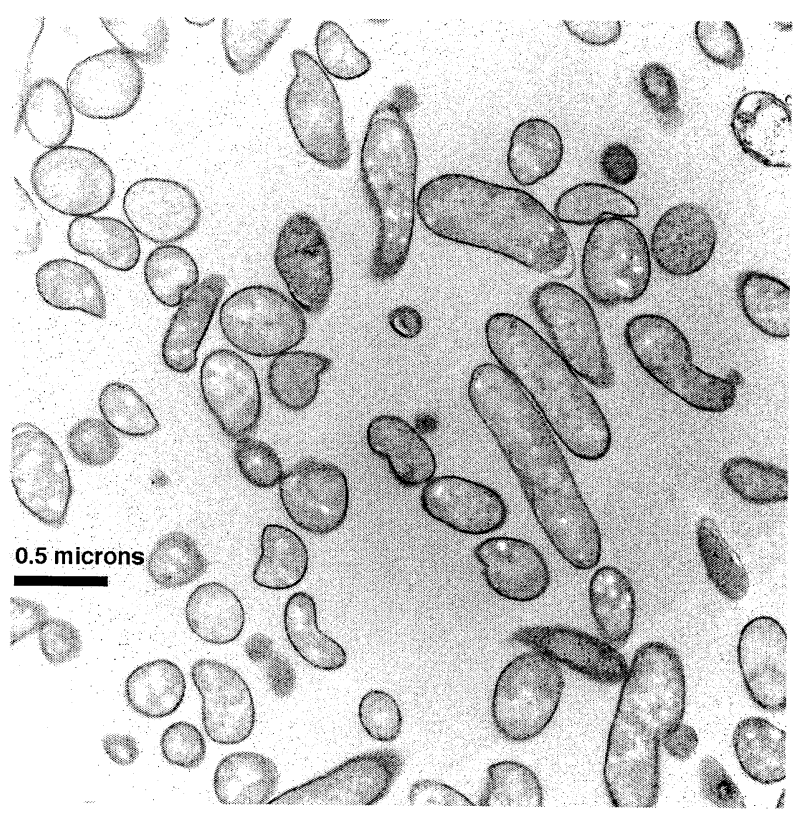

Fig. 11. Transmission electron micrograph of $P$. fluorescens cells exposed to $100 \mu \mathrm{mol} / \mathrm{L}$ uranyl. The samples have not been stained. High electron density corresponds to the presence of uranyl. The membranes (both outer and inner) are significantly darker than the cytoplasm which indicates that uranyl accumulates in the membranes and periplasm. 


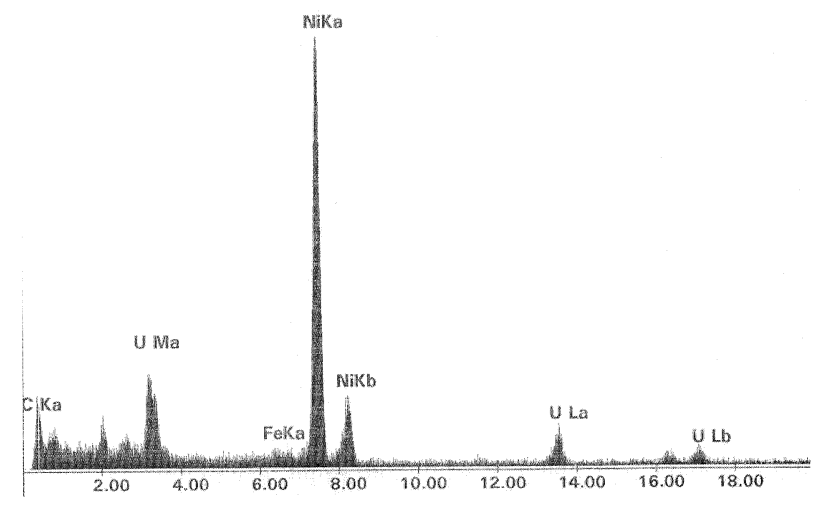

Fig. 12. Energy dispersive X-ray spectrum if the membrane of a cell exposed to uranyl. X-rays from the uranium $\mathrm{L}$ and $\mathrm{M}$ shells are clearly detectable, while no X-rays from Fe appear. The Ni signal comes from the grid.

\section{DISCUSSION}

This study shows that $P$. fluorescens, a common subsurface denitrifier, can serve as a ligand for uranyl. Under the conditions investigated (Fig. 2), cells rapidly scavenge solution uranyl and even outcompete citrate for uranyl, leading to the dissociation of preformed uranyl-citrate complex(es). Metabolically inactive cells also cause the dissociation of uranyl-citrate complex(es) and scavenge uranyl. Thus, the dissociation of uranyl-citrate complexes can be attributed to the depletion of uncomplexed uranyl by binding to the cell envelope, rather than to the depletion of uncomplexed citrate by biodegradation.

The ability of $P$. fluorescens to outcompete citrate for uranyl under the conditions studied is probably due to the low concentration of citrate present and the absence of other uranylbinding ligands (principally carbonate). As with all ligands, the amount of uranyl complexed by cells will vary according to the relative concentration of uranyl, cells, other ligands and $\mathrm{pH}$. One situation in which cells may complex a significant amount of uranyl is during the bioremediation of a low-carbonate site, where high cell concentrations are expected due to the bioaugmentation or biostimulation strategies.

Electron micrographs (Figs. 10 and 11) show the association of uranyl with both the outer and the cytoplasmic membranes as well as with the periplasm. A study of uranyl biosorption on another strain of $P$. fluorescens shows the association of uranyl with the cell envelope with the exception of $\sim 10 \%$ of the cells that accumulate uranyl intracellularly (Krueger et al., 1993). In that study, uranyl precipitates as platy crystals aligned in the periplasm so that their flat surfaces associate with the periplasm side of the outer and cytoplasmic membranes. It may be that those crystals are a uranyl phosphate phase formed during a cell wash with a phosphate buffer.

The present study scrupulously excluded phosphate. Spectroscopic and isotherm data both show no evidence of uranyl precipitation onto the cell surface (data not shown). Moreover, a rapid wash of uranyl-laden cells with bicarbonate released $\sim 90 \%$ of uranyl suggesting the presence of a labile uranyl-cell "complex" rather than a precipitate. Thus, we characterize the association of uranyl with cells as complexation. A similar complexation was described by Haas et al. (2001) for the association of uranyl with another gram-negative bacterium Shewanella putrefaciens.

The precise nature of the uranyl-cell complex is unknown. Researchers have suggested the importance of carboxyl and phosphato functional groups in the biosorption of uranyl by both gram-positive (Fowle et al., 2000; Kelly et al., 2001) and gram-negative bacteria (Haas et al., 2001; Kelly et al., 2002). We are currently investigating the molecular details of uranyl binding to the surface of $P$. fluorescens.

Under our experimental conditions, a large fraction of uranyl present is biosorbed and, consequently, a large fraction of citrate is uncomplexed (Fig. 1). Therefore, citrate is expected to be readily degraded by cells in the presence of uranyl because citrate is present to a large extent as either free citrate or $\mathrm{Kcit}^{2-}$, both biodegradable species. However, we observe little citrate degradation in the presence of some concentrations of uranyl ( $\geq 5 \mu \mathrm{mol} / \mathrm{L}$ ). Similarly, there is little glucose degradation in the presence of $3 \mu \mathrm{mol} / \mathrm{L}$ uranyl or higher. These results reveal the inhibitory effect of uranyl on cell metabolism of both citrate and glucose even at micromolar concentrations.

The inhibition appears to be associated with the binding of uranyl to the cell envelope. A cell wash with bicarbonate recovers $\sim 90 \%$ of uranyl and leads to a recovery $(30 \%)$ in metabolic activity of cells. The link between uranyl binding to the cell surface and the inhibitory effect of uranyl is important because it suggests that biosorption inhibits metabolism. The ease of reversibility of the inhibition by washing with a complexing agent strengthens the argument that the inhibitory effect of uranyl is not associated with intracellular intake of uranyl but rather with binding to the cell surface. We hypothesize that the binding of $U$ may alter the conformation of membrane proteins crucial for the metabolism of citrate and glucose or that uranyl biosorption reduces membrane fluidity and permeability, thus limiting citrate and glucose uptake. The cells recover only $30 \%$ of their activity after washing with bicarbonate even as $90 \%$ of uranyl is in solution, suggesting a hysteresis effect in the recovery from uranyl biosorption.

Several studies have described the toxic effect of uranyl on bacterial metabolism. An early study (Barron et al., 1948) documented the toxic effect of uranyl on yeast and bacteria, including Pseudomonas aeruginosa. Tuovinen and Kelly (1974a, 1974b) also recorded the toxic effect of uranyl on the iron oxidizer Thiobacillus ferrooxidans at acidic $\mathrm{pH}$. They found that the presence of a chelator such as EDTA or a high concentration of competing cations reduced the inhibitory effect of uranyl on $T$. ferrooxidans.

Huang et al. (1998) studied the degradation of citrate in the presence of uranyl by a growing mixed culture. At $\mathrm{pH} 6$, they found that $73 \%$ of citrate was degraded within $100 \mathrm{~h}$ when present in threefold excess but no further reduction took place in the following $140 \mathrm{~h}$. At that $\mathrm{pH}$, uranyl was sorbed to cells extensively $(\sim 50 \%)$. At higher citrate:uranyl ratios (8:1), complete citrate degradation was observed within $130 \mathrm{~h}$ at $\mathrm{pH} 6$ but less uranyl was associated with cells. For $\mathrm{pHs}$ at which solution carbonate limits $U$ sorption to cells (e.g., pH 8, 9), citrate degradation was unhindered and proceeded to $100 \%$ within $10 \mathrm{~h}$ even at low citrate:uranyl ratios. The authors attributed the difference in citrate degradation at $\mathrm{pH} 6$ and 8 to changes in uranyl speciation (carbonate vs. citrate complexes). Nonethe- 
less, there appears to be a correlation between incomplete citrate degradation and sorption of uranyl onto cells in their data. The study (Huang et al., 1998) was conducted under growth conditions, with a mixed bacterial community and with considerably higher uranyl and citrate concentrations ([uranyl] $=0.42 \mathrm{mmol} / \mathrm{L}$ and $[$ citrate $]=0.55-3.5 \mathrm{mmol} / \mathrm{L}$ ). Despite the major differences with conditions in our study, the effect of biosorbed uranyl on citrate biodegradation was also observed.

Other studies show different results. Joshi-Tope and Francis (1995) and Francis et al. (1992) found that P. fluorescens was unable to degrade citrate in the presence of equimolar uranyl. Cell free extract of the cells readily degraded $100 \%$ of citrate in the presence of equimolar uranyl. The authors suggested that the uranyl-citrate complexes had limited lability, rendering citrate non-bioavailable. Unfortunately, no uranyl measurements were made and thus was not possible to assess the fraction of uranyl sorbed to cells in those experiments.

The toxic species responsible for binding to cells and inhibiting metabolism was not identified in this study. However, due to the chemical simplicity of the system studied, only four species can be considered as possible inhibitors: $\mathrm{UO}_{2}{ }^{2+}$, $\mathrm{UO}_{2} \mathrm{Cl}^{+}, \mathrm{UO}_{2} \mathrm{OH}^{+}$and $\left(\mathrm{UO}_{2}\right)_{2}(\mathrm{OH})_{2}{ }^{2+}$. Only two hydroxide species are considered because, the inhibitory species is likely to be a cation due to its binding to the negatively charged surface of cells. Banaszak et al. (1999) concluded that a uranylcitrate complex was the toxic species. The design of our experiments does not allow a definitive conclusion on the toxicity of the uranyl-citrate complex. However, it is clear that there is at least one additional inhibitory species as inhibition was also observed in the absence of citrate.

\section{CONCLUSIONS}

This study shows that, under the conditions studied, the cellular envelope of $P$. fluorescens serves as a ligand for uranyl. Additionally, the binding of uranyl to the cell envelope results in the inhibition of cell metabolism. The inhibition is reversible by desorbing uranyl.

Acknowledgments-This work was supported by a grant from the Environmental Management Science Program in the Department of Energy (DE-FG07-96ER14698). We are indebted to Jonathan Mulholland for his generous help with sample preparation, microtomy and electron microscopy and for the use of the Biology Electron Microscopy Laboratory at Stanford University. Also, we would like to thank three anonymous reviewers for their constructive input.

Associate editor: J. B. Fein.

\section{REFERENCES}

Allen P. G., Shuh D. K., Bucher J. J., Edelstein N. M., Reich T., Denecke M. A., and Nitsche H. (1996) EXAFS determinations of uranium structures: The uranyl ion complexed with tartaric, citric, and malic acids. Inorg. Chem. 35, 784-787.

Banaszak J. E., Rittmann B. E., and Reed D. T. (1999) Subsurface interactions of actinide species and microorganisms: Implications for the bioremediation of actinide-organic mixtures. J. Radioanal. Nucl. Chem. 241, 385-435.

Barron E. S. G., Muntz J. A., and Gasvoda B. (1948) Regulatory mechanisms of cellular respiration I. The role of cell membranes: uranium inhibition of cellular respiration. J. Gen. Physiol. 32, 163178.

Coates J. D., Ellis D. J., Gaw C. V., and Lovley D. R. (1999) Geothrix fermentans gen. nov., sp nov., a novel Fe(III)-reducing bacterium from a hydrocarbon-contaminated aquifer. Int. J. Sys. Bact. 49 , $1615-1622$

Department of Energy (1997) Integrated Data Base Report-1996: U.S. Spent Nuclear Fuel and Radioactive Waste Inventories, Projections, and Characteristics. Revision 13, December 1997. http:// www.em.doe.gov/idb97/contents.html.

Department of Energy (1998) Fiscal Year 1997 Integrated Water Quality Program Annual Report for the U.S. Department of Energy Oak Ridge National Reservation, Oak Ridge, Tennessee, BJC/OR32. U.S. Department of Energy, Washington, DC. Prepared by Science Applications International Corp.

Dodge C. J. and Francis A. J. (1997) Biotransformation of binary and ternary citric acid complexes of iron and uranium. Environ. Sci. Technol. 31, 3062-3067.

Feldman I., Havill J. R., and Newman W. F. (1954) Polymerization of uranyl-citrate, -malate, -tartrate and -lactate complexes. J. Am. Chem. Soc. 76, 4726-4732.

Fowle D. A., Fein J. B., and Martin A. M. (2000) Experimental study of uranyl adsorption onto Bacillus subtilis. Environ. Sci. Technol. 34, $17,3737-3741$

Francis A. J., Dodge C. J., and Gillow J. B. (1992) Biodegradation of metal citrate complexes and implications for toxic-metal mobility. Nature 356, 140-142.

Fuller M. E. and Scow K. M. (1997) Lack of capsular exopolymer effects on the biodegradation of organic compounds by Pseudomonas sp. strains JS1 and JS150. Microbiol. Ecol. 34, 248-253.

Grenthe I., Fuger J., Konings R. J. M., Lemire R. J., Muller A. B., Nguyen-Trung C., and Wanner H. (1992) Chemical Thermodynamics of Uranium. Nuclear Energy Agency, OECD, Paris.

Haas J. R., DiChristina T. J., and Wade R., Jr. (2001) Thermodynamics of U(VI) sorption onto Shewanella putrefaciens. Chem. Geol. 180, 33-54.

Hartman M. J., Morasch L. F., and Webber W. D. (2000) Hanford Site Groundwater Monitoring for Fiscal Year 1999. http://hanford.pnl. gov/groundwater/reports/gwrep99/html/start1.htm.

Huang F. Y. C., Brady P. V., Lindgren E. R., and Guerra P. (1998) Biodegradation of uranium-citrate complexes: Implications for extraction of uranium from soils. Environ. Sci. Technol. 32, 379-382.

Hugenholtz J. (1993) Citrate metabolism in lactic-acid bacteria. FEMS Microbiol. Rev. 12, 165-178.

Joshi-Tope G. and Francis A. J. (1995) Mechanisms of biodegradation of metal-citrate complexes by Pseudomonas fluorescens. J. Bacteriol. 177, 1989-1993.

Kelly S. D., Boyanov M. I., Bunker B. A., Fein J. B., Fowle D. A., Yee N., and Kemner K. M. (2001) XAFS determination of the bacterial cell wall functional groups responsible for complexation of $\mathrm{Cd}$ and $\mathrm{U}$ as a function of pH. J. Synchrotron Rad. 8, 946-948.

Kelly S. D., Kemner K. M., Fein J. B., Fowle D. A., Boyanov M. I., Bunker B. A., and Yee N. (2002) X-ray absorption fine structure determination of $\mathrm{pH}$-dependent U-bacterial cell wall interactions. Geochim. Cosmochim. Acta 66, 3855-3871.

Krueger S., Olson G. J., Johnsonbaugh D., and Beveridge T. J. (1993) Characterization of the binding of gallium, platinum, and uranium to Pseudomonas fluorescens by small-angle $\mathrm{X}$-ray scattering and transmission electron microscopy. Appl. Environ. Microbiol. 59, 4056-4064.

Langmuir D. (1997) Aqueous Environmental Geochemistry. Prentice Hall, New York.

Lenhart J. J., Cabaniss S. E., MacCarthy P., and Honeyman B. D. (2000) Uranium(VI) complexation with citric, humic and fulvic acids. Radiochim. Acta 88, 345-353.

Markovits G., Klotz P., and Newman L. (1972) Formation constants for the mixed-metal complexes between indium(III) and uranium(VI) with malic, citric and tartaric acids. Inorg. Chem. 11, 2405-2408.

Newman W. F., Havill J. R., and Feldman I. (1951) The uranyl: citrate system. II. Polarographic studies of the 1:1 complex. J. Am. Chem. Soc. 73, 3593-3595.

Nunes M. T. and Gil V. M. S. (1987) New NMR evidence on the uranyl-citrate complexes. Inorg. Chim. Acta 129, 283-287.

Papelis C., Hayes K. F., and Leckie J. O. (1988) HYDRAQL: A Program for the Computation of Chemical Equilibrium Composition of Aqueous Batch Systems Including Surface-Complexation Modeling of Ion Adsorption at the Oxide/Solution Interface. Stanford University, Stanford, CA. 
Rajan K. S. and Martell A. E. (1965) Equilibrium studies of uranyl complexes. III. Interaction of uranyl ion with citric acid. Inorg. Chem. 4, 462-468.

Redden G. D., Li J., and Leckie J. O. (1998) Adsorption of U(VI) and citric acid on goethite, gibbsite and kaolinite. In Adsorption of Metals by Geomedia (ed. E. A. Jenne), chap. 13 Academic Press, San Diego, CA.

Riley R. G., Zachara J. M., and Wobber F. J. (1992) Chemical Contaminants on DOE Lands and Selection of Contaminant Mixtures for Subsurface Science Research. U.S. Department of Energy, Washington, DC.
Smith R. M, Martell A. E (1997) NIST Critically Selected Stability Constants for Metal Complexes Database. NIST Standard Reference Data, Gaithersburg, MD.

Tuovinen O. H. and Kelly D. P. (1974a) Studies of the growth of Thiobacillus ferrooxidans II. Toxicity of uranium to growing cultures and tolerance conferred by mutation, other metal cations and EDTA. Arch. Microbiol. 95, 153-164.

Tuovinen O. H. and Kelly D. P. (1974b) Studies of Thiobacillus ferrooxidans IV. Influence of monovalent metal cations on ferrous iron oxidation and uranium toxicity in growing cultures. Arch. Microbiol. 98, 167-174. 